\title{
Effects of lime-induced differences in site fertility on fine roots of oak
}

\author{
Mark R. Bakker, Claude Nys* \\ Équipe cycles biogéochimiques, Inra Nancy, 54280 Champenoux, France
}

(Received 9 March 1999 ; accepted 9 June 1999)

\begin{abstract}
This study aims at evaluating the effects of lime-induced differences in site fertility on fine roots. Lime was applied to ten oak (Quercus petraea and $Q$. robur) stands on acidic soils with low base saturation, 1-27 years before fine root sampling. The soil exchangeable nutrient pool, fine root and foliar composition all showed deficient levels for at least a number of elements. Liming enhanced fine root biomass both in topsoil and in deeper horizons, and overall fertility and nutrition were improved for Ca and Mg but not for $\mathrm{K}$ and $\mathrm{P}$. Thus, liming in moderate doses on acidic sites showing nutrient deficiencies may stimulate the absorbing capacity of the tree root system by enlarging fine root standing crop and thereby improving uptake of mineral nutrients and stand growth. However, one should bear in mind that resolving a deficiency for some elements can create less favourable conditions for others. (C) 1999 Éditions scientifiques et médicales Elsevier SAS.
\end{abstract}

fine roots / liming / mineral nutrition / Quercus / soil

Résumé - Conséquences, après amendement, d'un changement de fertilité sur les racines fines de chêne. Cette étude évalue l'effet des changements induits au niveau de la fertilité du sol par des amendements calciques et ses conséquences sur les racines fines. Les amendements calciques ont été appliqués dans dix peuplements de chêne (Quercus petraea et robur) sur des sols acides et désaturés, entre 1 et 27 ans avant l'échantillonnage des racines fines. Ces dix peuplements montraient des déficiences nutritives déterminées par le niveau des stocks d'éléments échangeables, la composition minérale des racines et des feuilles. Les amendements ont augmenté la biomasse racinaire en surface et en profondeur et la nutrition de Ca et $\mathrm{Mg}$, mais pas celle de $\mathrm{P}$ et $\mathrm{K}$. Un amendement calcique modéré, sur des sols acides avec des déficiences nutritives, peut ainsi stimuler le système d'absorption de l'arbre en augmentant la biomasse racinaire, et secondairement la nutrition minérale et la croissance des arbres. Il est important de signaler que l'effet sur d'autres éléments nutritifs, non apportés, peut être moins favorable et même déséquilibrer le système dans un autre sens. (C) 1999 Éditions scientifiques et médicales Elsevier SAS.

amendement calcique / nutrition minérale / Quercus / racine fine / sol

\section{Introduction}

For the purpose of evaluating forest productivity, vitality and soil resources, the interface between soil nutrient pools and tree roots as uptake organs to sustain above-ground growth, is of utmost importance. A suffi- cient level of nutrient resources in the soil (in plantavailable form) is needed to ensure a sustained productivity and vitality of the forest stands. Uptake of $\mathrm{Mg}^{2+}$ or $\mathrm{Ca}^{2+}$ can be strongly depressed when in competition with other cations such as $\mathrm{K}^{+}, \mathrm{NH}_{4}^{+}, \mathrm{Al}^{3+}$ or $\mathrm{H}^{+}$[14]. Thus, not all of the potentially available soil nutrients

\footnotetext{
* Correspondence and reprints tel: $+33(0) 383394073$; fax: + $33(0) 383394069$ e-mail: nys@nancy.inra.fr
} 
are accessible to tree roots owing to such an antagonistic uptake [15]. A way of evaluating the root function, that is root health and thus uptake potential, is the use of $\mathrm{Ca} / \mathrm{Al}$ ratios in the tissue of fine roots $[1,6] ; \mathrm{Ca} / \mathrm{Al}$ ratios below the threshold levels indicate potential toxicity and physiological disturbance. As allocation of nutrients, after uptake, is often preferential to the canopy relative to the roots, fine roots can be good additional indicators of change in nutritional conditions in forest stands [12]. They can be very useful as stress indicators at an early stage before major deficiencies can be detected at the foliar level $[8,20]$. Ten oak stands mostly situated on poor acidic forest soils were included in this study. They featured deficiencies for one or more nutrients (amongst which Ca was generally deficient). Lime as a "compensation amendment" was expected to increase fertility and productivity of these stands. The objective of this paper was to determine the lime-induced changes in soil fertility and total mineral nutrition of trees and their relationship to fine root development. In a previous paper [1] the effects of liming on soil chemistry, element concentrations in roots and foliage, fine root development and stand growth were described. Here, the focus is more on general site fertility and nutrition.

\section{Materials and methods}

Between June 1994 and March 1996 a total of ten different sites with Oak (Quercus petraea and $Q$. robur) were sampled for measurement of soil, fine root, foliage and above-ground growth parameters. Eight of the trials are situated in France and two in the south-east of the
Netherlands (sites 9 and 10). The lime treatments were in form of $\mathrm{CaCO}_{3}$ or $\mathrm{CaO}$. In addition to the lime amendment some complementary compounds were used: $\mathrm{N}$ (sites 4-6), N, P and $\mathrm{K}$ (site 8 ) and $\mathrm{Mg}$ (3.5\% in the lime product on sites 9 and 10). The levels of these additions were low, especially for the $\mathrm{N}$ which was only applied in the oldest sites (26-27 years ago), and it was assumed that it would not have an influence on the present tree response [3]. Soil and fine roots were sampled by soil coring down to a maximum of $75 \mathrm{~cm}$ (table $D$ and were treated separately for each soil layer (generally layers of $15 \mathrm{~cm}$ with the first layer separated into 0-5 and $5-15 \mathrm{~cm}$ ), although summed values or averages over the total profile were sometimes used as an additional variable. Sample number was generally between two and four per soil layer and treatment for chemical analyses (soil and fine roots) and between 16 and 18 for fine roots (weight, length), but this varied for the different experimental sites. Foliage was sampled in August close to the top of the crown of five dominant trees per experimental plot and above-ground tree growth was evaluated by means of height, diameter at breast height $(\mathrm{DBH})$ and analysis of ring width on wood cores.

All individual samples (per point and layer) were processed separately. Soil samples were air-dried and then sieved at $2 \mathrm{~mm}$. ICP (emission spectrometry) was used to determine $0.5 \mathrm{M} \mathrm{NH}_{4} \mathrm{Cl}$-exchangeable $\mathrm{Al}, \mathrm{Ca}$, $\mathrm{Mg}, \mathrm{K}, \mathrm{Mn}$ and $\mathrm{Na}$ [17], automatic titration to determine exchangeable acidity [17], and $\mathrm{pH}$-electrodes to determine $\mathrm{pH}-\mathrm{KCl}$ and $\mathrm{pH}-\mathrm{H}_{2} \mathrm{O}$ following standard procedures and a 1:2.5 dilution basis. Concentrations were expressed on an oven-dried $\left(105^{\circ} \mathrm{C}\right)$ weight basis. The fine roots $(<2 \mathrm{~mm}$ in diameter) were separated from the

Table I. Site characteristics of the ten limed oak stands.

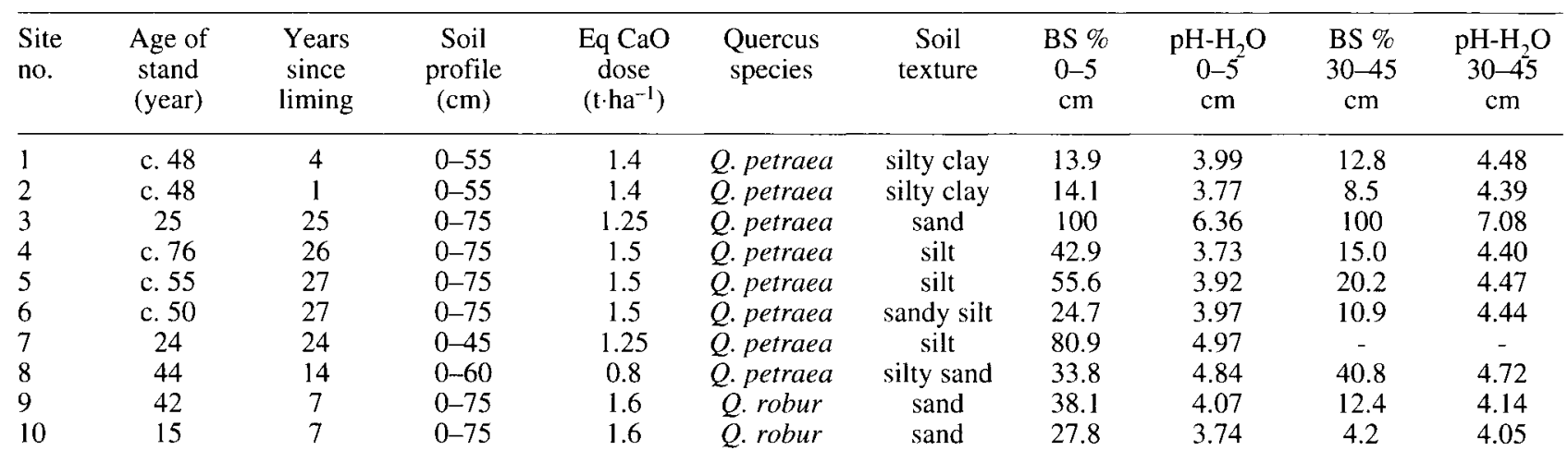

1, Croix-Scaille ancient; 2, Croix-Scaille recent; 3, Fontainebleau; 4, Trembles; 5, Gaie Mariée; 6, Rond du May; 7, Bertranges; 8, Tronçais; 9, St. Anthonis 35c; 10, St. Anthonis 46a.

BS $\%=\%$ base saturation. 
soil by wet sieving above a 4 - and 2 -mm sieve followed by short flotation to rinse the roots and root length was estimated by the line intersection method [16]. The fine root dry weight was obtained by drying at $105^{\circ} \mathrm{C}$ to constant weight. Correction factors for losses due to stocking, and passing through the sieve were established and evaluated at $+20 \%$ for weight and at $+25 \%$ for length. For the chemical analyses of foliage and fine roots, subsamples were pre-treated with peroxide $\left(\mathrm{H}_{2} \mathrm{O}_{2}\right)$, then mineralized with $\mathrm{HClO}_{4}$ and analysed by ICP. For additional information on the methods, see Bakker [1].

The amounts of exchangeable nutrients in the soil were calculated by multiplying the concentration determined on soil samples by the average soil density of the different layers. These soil densities were either known or estimated using general site characteristics such as texture and soil density values for similar sites in the Renecofor sites [5]. The amounts of nutrients in fine roots were calculated by multiplying the concentrations in the fine roots by the dry weight of fine roots per soil layer, before summing these values on a hectare and profile basis. Since sampling was carried out only for a limited number at the deepest layers, these summed values were not tested for treatment effects. Instead, treatment effects were established by analysis of variance within individual horizons. The Student-Newman-Keuls test was used to establish significant differences between group means with Unistat 4.0 software [18].

\section{Results}

The quantities of exchangeable elements are presented in table II and figure 1 . The quantity of exchangeable $\mathrm{Ca}$ and $\mathrm{Mg}$ was increased by liming, but this was noticeable only in the most recently limed stands. All together, based on individual horizons, this increase in Ca was significant only for the most recently limed stands. An

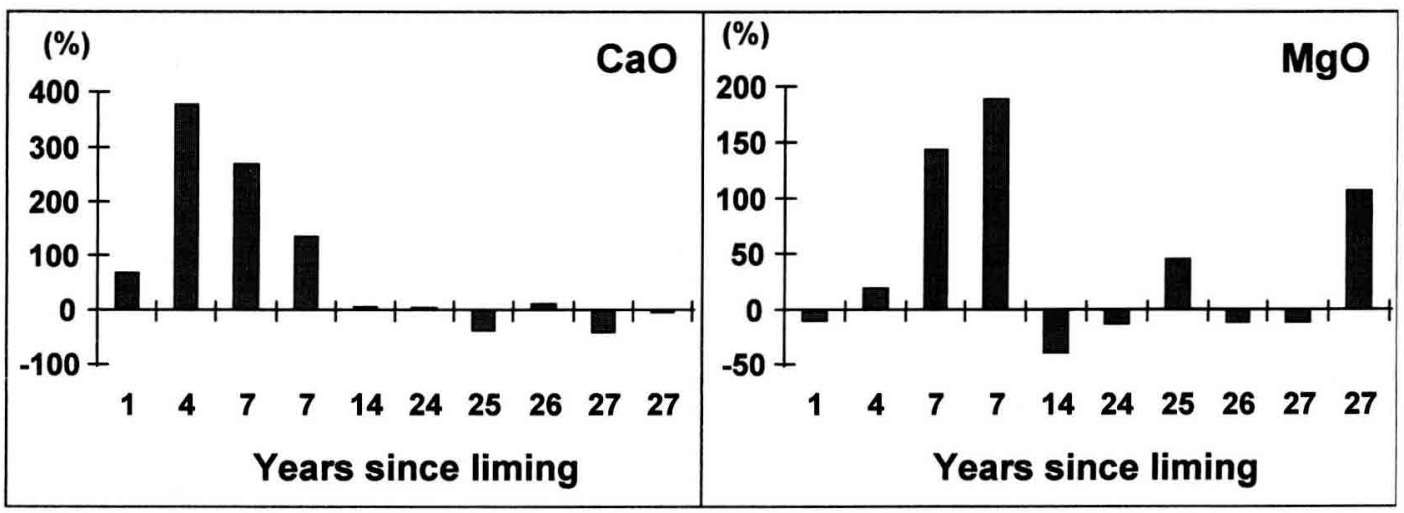

Figure 1. Limeinduced change (\%) of soil $\mathrm{Ca}$ or $\mathrm{Mg}$ (kg CaO or $\mathrm{MgO} \mathrm{ha}{ }^{-1}$ ) as a function of time since liming (sum of total soil profile).

Table II. Amounts of exchangeable elements in $\mathrm{kg} \cdot \mathrm{ha} \mathrm{a}^{-1}$; soil fertility evaluated as poor or very poor for Ca $(<600$ and $<415 \mathrm{~kg}$ $\mathrm{CaO} \cdot \mathrm{ha}^{-1}$ resp.), for $\mathrm{Mg}\left(<220\right.$ and $<150 \mathrm{~kg} \mathrm{MgO} \cdot \mathrm{ha}^{-1}$ resp.), for $\mathrm{K}\left(<400\right.$ and $<290 \mathrm{~kg} \mathrm{~K}_{2} \mathrm{O} \cdot \mathrm{ha}^{-1}$ resp.) and for $\mathrm{P}(<760$ and $<280$ $\mathrm{kg} \mathrm{P}_{2} \mathrm{O}_{5} \cdot \mathrm{ha}^{-1}$ resp.).

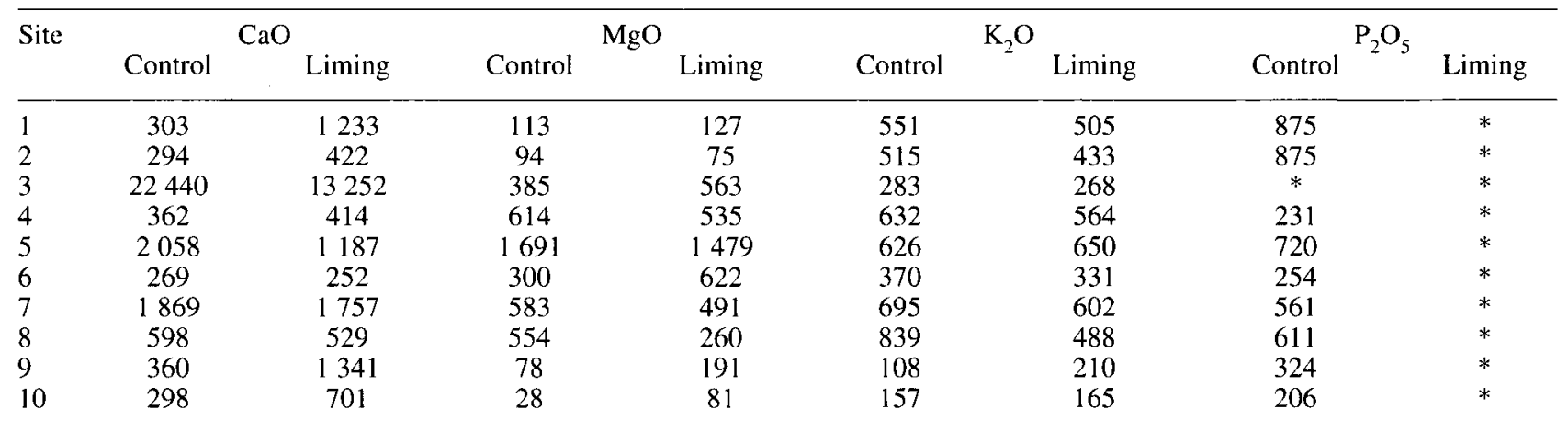

Values are sums of the profile $\left({ }^{*}=\right.$ limed stands not assessed for $\left.\mathrm{P}\right)$ and threshold values are derived from Bonneau [3]. 
apparent decrease in exchangeable $\mathrm{Ca}$ at sites 3 and 5 is due to a lime-rich layer in the subsoil, explaining the high total values of $\mathrm{Ca}$ in the control plots; in the top layers liming increased the total amount of $\mathrm{Ca}$. Effects of liming on $\mathrm{K}$ were less clear: some increases and some decreases. The total amounts of $\mathrm{K}$ may have declined slightly.

The total amount of $\mathrm{Mg}$ and $\mathrm{Ca}$ in the fine roots (table III) was increased in most cases (for seven out of ten sites), although this failed to be significant in most stands owing to the limited sample number per soil layer; effects on $\mathrm{P}$ and $\mathrm{K}$ were not conclusive. The concentrations of these elements in the fine roots showed a marginal increase as shown by the overall mean values ( \pm standard errors) for $\mathrm{Ca}(2.3 \pm 0.22$ and $2.6 \pm 0.27 \mathrm{~g}$ $\mathrm{kg}^{-1}$ dry weight for control and liming, respectively), whereas concentrations of $\mathrm{Mg}(0.95 \pm 0.04$ and 0.98 $\pm 0.03)$, of $K(0.93 \pm 0.03$ and $0.87 \pm 0.05)$ and $P(0.51$ \pm 0.03 and $0.51 \pm 0.03$ ) were not clearly affected [1] The parts of the soil profile below the $\mathrm{Ca} / \mathrm{Al}$ thresholds $[1,6]$ of the tissue of the fine roots in the control and lime treatments and the net effects of liming are presented in table $I V$. It shows that at most of the sites fine root critical $\mathrm{Ca} / \mathrm{Al}$ ratios occur in at least a part of the soil profile [6], and that liming increased this $\mathrm{Ca} / \mathrm{Al}$ ratio in many soil layers.

According to absolute nutrient levels [3, 19], liming only succeeded in improving foliar nutrition out of the critical range for $\mathrm{Ca}$, and occasionally for $\mathrm{Mg}$ (table $\mathrm{V}$ ). This lime-induced increase in foliar $\mathrm{Ca}$ and $\mathrm{Mg}$ was consistent throughout all liming trials, and only slightly lower for the sites with the greatest time lapse since liming. The $\mathrm{Ca} / \mathrm{N}$ and $\mathrm{Mg} / \mathrm{N}$ values show the same limeinduced stimulation and consistency over time.

Table III. Total amount of four macroelements in the fine roots as a function of liming; values are sums for the total profile $\left(\mathrm{kg} \cdot \mathrm{ha}^{-1}\right)$.

\begin{tabular}{lcccccccc}
\hline Site & $\begin{array}{c}\mathrm{Ca} \\
\text { Control }\end{array}$ & Lime & $\begin{array}{c}\mathrm{Mg} \\
\text { Control }\end{array}$ & Lime & $\begin{array}{c}\mathrm{K} \\
\text { Control }\end{array}$ & Lime & $\begin{array}{c}\mathrm{P} \\
\text { Control }\end{array}$ & Lime \\
\hline 1 & 14.86 & 11.17 & 4.89 & 5.41 & 5.63 & 6.51 & 2.98 & 1.34 \\
2 & 3.65 & 4.47 & 2.49 & 2.53 & 3.46 & 2.95 & 2.15 & 1.89 \\
3 & 29.81 & 57.11 & 3.69 & 5.47 & 1.91 & 7.13 & 0.50 & 0.51 \\
4 & 4.77 & 5.36 & 3.44 & 3.52 & 2.80 & 2.80 & 1.43 & 2.15 \\
5 & 4.46 & 7.98 & 3.25 & 3.09 & 2.42 & 2.18 & 1.02 & 1.24 \\
6 & 9.69 & 9.20 & 8.08 & 5.94 & 7.98 & 5.08 & 1.90 & 1.04 \\
7 & 5.48 & 9.35 & 2.75 & 4.11 & 1.98 & 2.14 & 1.06 & 3.44 \\
8 & 8.53 & 7.80 & 5.08 & 4.79 & 5.08 & 5.11 & 4.53 & 5.45 \\
9 & 11.38 & 16.95 & 4.62 & 5.91 & 3.67 & 3.23 & 3.44 & 2.98 \\
10 & 10.94 & 11.18 & 3.41 & 4.28 & 3.07 & 2.69 & & \\
\hline
\end{tabular}

Table IV. Fine root tissue $\mathrm{Ca} / \mathrm{Al}$ molar ratios as a function of liming: the soil horizons are presented in $\mathrm{cm}$ where these ratios are below the general toxicity threshold levels $<0.2$ and $<0.5$.

\begin{tabular}{|c|c|c|c|c|c|c|}
\hline \multirow[t]{2}{*}{$\begin{array}{l}\text { Site } \\
\text { no. }\end{array}$} & \multicolumn{2}{|c|}{$\begin{array}{l}\text { Part below threshold in the } \\
\text { control }\end{array}$} & \multicolumn{2}{|c|}{$\begin{array}{l}\text { Part below threshold in the } \\
\text { lime treatment }\end{array}$} & \multirow{2}{*}{$\begin{array}{l}\text { Net positive } \\
\text { effect } \\
\text { on root } \mathrm{Ca} / \mathrm{Al}\end{array}$} & \multirow{2}{*}{$\begin{array}{c}\text { Net negative } \\
\text { effect } \\
\text { on root } \mathrm{Ca} / \mathrm{Al}\end{array}$} \\
\hline & $\begin{array}{l}\operatorname{root~} \mathrm{Ca} / \mathrm{Al} \\
\quad<0.2\end{array}$ & $\begin{array}{c}\operatorname{root} \mathrm{Ca} / \mathrm{Al} \\
0.2-0.5\end{array}$ & $\begin{array}{l}\operatorname{root} \mathrm{Ca} / \mathrm{Al} \\
\quad<0.2\end{array}$ & $\begin{array}{c}\operatorname{root} \mathrm{Ca} / \mathrm{Al} \\
0.2-0.5\end{array}$ & & \\
\hline 1 & $5-55$ & $0 \sim 5$ & $5-55$ & - & $0-30$ & \\
\hline 2 & $5-55$ & $0-5$ & $5-55$ & $0-5$ & $0-5$ & \\
\hline 3 & $*$ & $*$ & $*$ & $*$ & * & * \\
\hline 4 & $15-60$ & $5-15$ & $5-15 / 30-60$ & $15-30$ & $15-45$ & $5-15 / 45-60$ \\
\hline 5 & $15-30 / 45-60$ & $5-15 / 30-45$ & - & $15-45$ & $0-60$ & \\
\hline 6 & $15-60$ & $5-15$ & $45-60$ & $5-45$ & $0-5 / 15-60$ & \\
\hline 7 & $0-5$ & $5-30$ & - & $0-30$ & $0-30$ & \\
\hline 8 & - & $0-45$ & $30-45$ & $0-30$ & $15-30$ & $30-45$ \\
\hline 9 & $30-60$ & $5-30$ & $45-60$ & $5-45$ & $15-60$ & $0-15$ \\
\hline 10 & $15-60$ & $5-15$ & $30-60$ & $15-30$ & $0-30$ & \\
\hline
\end{tabular}

The treatment effects are summarized in italics in the two columns on the right $\left(^{*}=\right.$ missing data; empty fields mean not appropriate, not occurring). 
Table V. Deficiencies and alleviation by liming according to foliar composition thresholds (poor $=<2 \% \mathrm{~N},<0.13 \% \mathrm{P}$ for $Q$. petrae a and $<0.14 \%$ for $Q$. robur, $<0.60 \% \mathrm{~K},<0.30 \% \mathrm{Ca}$ for $\mathrm{Q}$. petraea and $<0.50 \%$ for $\mathrm{Q}$. robur, and $<0.15 \% \mathrm{Mg}$ for $\mathrm{Q}$. petraea and $<0.16 \%$ for Q. robur; based on Bonneau [3] and on Van den Burg and Olsthoorn [19]); further expressed relative to nitrogen $(100 \times$ nutrient percentage $\mathrm{DW} / \mathrm{N}$ percentage $\mathrm{DW})$

\begin{tabular}{|c|c|c|c|c|c|c|c|c|c|c|}
\hline \multirow{2}{*}{$\begin{array}{l}\text { Site } \\
\text { no. }\end{array}$} & \multirow{2}{*}{$\begin{array}{l}\text { Foliage } \\
\text { Control }\end{array}$} & \multirow{2}{*}{$\begin{array}{l}\text { Foliage } \\
\text { Lime }\end{array}$} & \multicolumn{2}{|c|}{$\mathrm{Ca} / \mathrm{N}$} & \multicolumn{2}{|c|}{$\mathrm{Mg} / \mathrm{N}$} & \multicolumn{2}{|c|}{$\mathrm{K} / \mathrm{N}$} & \multicolumn{2}{|c|}{$\mathrm{P} / \mathrm{N}$} \\
\hline & & & Control & Lime & Control & Lime & Control & Lime & Control & Lime \\
\hline 1 & $\mathrm{Ca}, \mathrm{Mg}$ & $\mathrm{Mg}$ & 12.3 & 18.9 & 3.5 & 4.0 & 31.3 & 31.7 & 6.6 & 5.7 \\
\hline 3 & $\mathrm{Mg}, \mathrm{P}, \mathrm{K}$ & $\mathrm{P}, \mathrm{K}$ & 37.9 & 46.0 & 7.2 & 7.9 & 27.4 & 28.4 & 4.0 & 3.7 \\
\hline 4 & N,P & $\mathrm{N}, \mathrm{P}$ & 40.3 & 40.7 & 8.4 & 8.7 & 40.6 & 36.2 & 6.0 & 5.2 \\
\hline 5 & N,P & $\mathrm{P}$ & 34.2 & 35.1 & 8.7 & 8.2 & 35.3 & 37.3 & 5.2 & 4.8 \\
\hline 8 & - & - & 33.5 & 40.2 & 7.9 & 8.5 & 40.9 & 40.2 & 6.1 & 7.8 \\
\hline 9 & - & - & 19.9 & 26.0 & 6.8 & 7.8 & 28.8 & 29.9 & 6.4 & 6.4 \\
\hline 10 & $\mathrm{P}$ & $\mathbf{P}$ & 26.7 & 41.0 & 9.5 & 11.4 & 33.8 & 31.9 & 6.2 & 5.7 \\
\hline
\end{tabular}

DW = dry weight.

Table VI. Ratios of root elements/foliar N $(100 \times$ nutrient $\%$ DW of root $/ \mathrm{N} \% \mathrm{DW}$ of foliage $)$.

\begin{tabular}{|c|c|c|c|c|c|c|c|c|}
\hline \multirow[t]{2}{*}{ Site } & \multicolumn{2}{|c|}{$\mathrm{Ca} / \mathrm{N}$} & \multicolumn{2}{|c|}{$\mathrm{Mg} / \mathrm{N}$} & \multicolumn{2}{|c|}{$\mathrm{K} / \mathrm{N}$} & \multicolumn{2}{|c|}{$\mathrm{P} / \mathrm{N}$} \\
\hline & Control & Lime & Control & Lime & Control & Lime & Control & Lime \\
\hline 1 & $19.1(1.8)$ & $12.4(0.6)$ & $6.5(0.5)$ & $6.6(0.9)$ & $8.0(1.2)$ & $7.8(0.3)$ & $4.2(0.7)$ & $1.3(0.3)$ \\
\hline 3 & $41.5(9.5)$ & $56.2(8.8)$ & $4.8(0.5)$ & $5.3(0.7)$ & $2.7(0.5)$ & $7.0(0.2)$ & $0.5(0.4)$ & $0.6(0.4)$ \\
\hline 4 & $5.3(0.8)$ & $5.4(1.1)$ & $3.9(0.4)$ & $3.8(0.2)$ & $3.4(0.2)$ & $3.2(0.8)$ & $1.5(0.3)$ & $2.4(0.8)$ \\
\hline 5 & $6.7(0.9)$ & $11.0(0.3)$ & $4.6(0.3)$ & $4.3(0.3)$ & $3.7(0.2)$ & $3.1(0.2)$ & $1.4(0.2)$ & $1.6(0.3)$ \\
\hline 8 & $10.8(I .0)$ & $8.8(0.9)$ & $6.4(0.2)$ & $5.4(0.2)$ & $6.5(0.5)$ & $5.7(0.2)$ & $2.3(0.1)$ & $3.8(0.3)$ \\
\hline 9 & $6.1(1.1)$ & $8.5(0.8)$ & $2.5(0.3)$ & $3.0(0.2)$ & $2.0(0.1)$ & $1.6(0.2)$ & $2.4(0.2)$ & $2.8(0.4)$ \\
\hline 10 & $7.6(2.0)$ & $8.7(2.6)$ & $2.5(0.5)$ & $3.5(0.8)$ & $2.6(0.3)$ & $2.5(0.8)$ & $2.9(0.2)$ & $2.7(0.2)$ \\
\hline
\end{tabular}

Root element values are average values of all soil layers (standard errors in italic); DW $=$ dry weight.

However, for $\mathrm{P}$ and $\mathrm{K}$, the values relative to $\mathrm{N}$ were less positive than were absolute foliar levels. Absolute levels showed some decrease in $\mathrm{P}$ level (six sites decrease, one increase, three no effect) and there was no clear effect on $\mathrm{K}$ (five sites increase, five sites decrease). The values relative to $\mathrm{N}$ indicated a decrease in eight out of ten for $\mathrm{P} / \mathrm{N}$ and some changes in $\mathrm{K} / \mathrm{N}$ ratios for the oldest lime trials in particular. The increase in $\mathrm{P} / \mathrm{N}$ occurred principally at site 8 , where some $\mathrm{P}$ was supplied with the lime treatment. Most of the values relative to $\mathrm{N}$ are normal compared to the values given by Boxman et al. [4] $(\mathrm{Mg} / \mathrm{N} \geq 5, \mathrm{~K} / \mathrm{N} \geq 25$ and $\mathrm{P} / \mathrm{N} \geq 5)$ or close to normal with low values at sites $3(\mathrm{P} / \mathrm{N})$ and 1 and $2(\mathrm{Mg} / \mathrm{N})$.

The fine root concentrations of nutrients relative to foliar $\mathrm{N}$ are presented in table $V I$, as the dataset for root $\mathrm{N}$ was not complete. The values are in general positive for root $\mathrm{Ca}$ and $\mathrm{Mg}$ as compared to foliar $\mathrm{N}$ (increase by liming), showing no nutritional disturbances $[4,20]$. The decrease in $\mathrm{Ca} / \mathrm{N}$ and $\mathrm{Mg} / \mathrm{N}$ ratios for site 8 may be due to the fact that $\mathrm{N}$ was also added on that particular site. Thus, the effect of lime on the values of the ratio of root $\mathrm{Ca}$ and root $\mathrm{Mg}$ to foliar $\mathrm{N}$ closely resemble those for the ratios of foliar to foliar $\mathrm{N}$ levels (table $V$ ). For the $\mathrm{P} / \mathrm{N}$ and $\mathrm{K} / \mathrm{N}$ ratios this was different (figure 2). As can be seen in this figure, for the $\mathrm{P} / \mathrm{N}$ ratios, the effect of liming (expressed as nutrient level relative to $\mathrm{N}$ ) is not very evident in the fine roots (no clear tendency), but in the foliage the $\mathrm{P} / \mathrm{N}$ ratios (indicated by the symbols) tend to decrease after liming. For the $\mathrm{K} / \mathrm{N}$ ratios the opposite is true: the foliar/foliar ratio is not clearly affected by liming (indicated by the symbols), while the root/foliar ratios tend to decrease. 

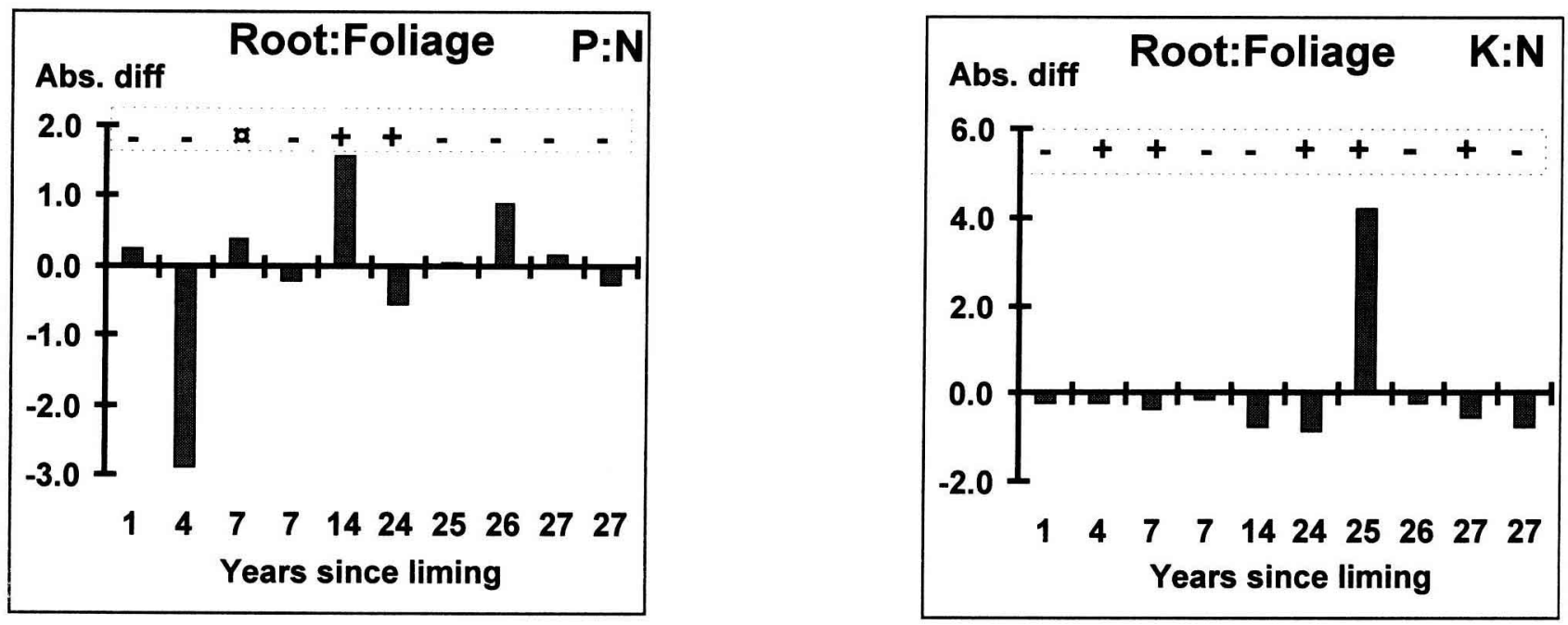

Figure 2. Lime-induced change (absolute difference) of nutrition ratios of root $\mathrm{P}$ and $\mathrm{K}$ : foliar $\mathrm{N}$ as a function of time since liming; the symbols in the upper part of the figure present the effects of lime on the foliar $\mathrm{P} / \mathrm{N}$ and $\mathrm{K} / \mathrm{N}$ nutrient ratios $(+=$ lime increased this value; $-=$ lime decreased this value and $a=$ lime did not change this value).

\section{Discussion}

The adaptation of root systems to acidic soils can be achieved either by an efficient nutrient uptake, efficient utilisation of nutrients or both [10]. At poor sites allocation of assimilates to fine roots is generally higher [11], for example when $\mathrm{N}, \mathrm{P}$ or $\mathrm{S}$ are deficient [9]. Conversely, when subsoil acidification enhances $\mathrm{Mg}$ or Ca deficiency due to an imbalance in uptake, an improvement of fertility and alkalinity (by lime) may increase fine root growth [9]. In the ten oak stands included in this work, liming generally stimulated fine root development and stand growth and these effects were detectable until at least 20-25 years after the lime treatments [1]. Whether this stimulation is the result of a resolved deficiency or conversely an investment optimising uptake of nutrients that are most deficient [7], depends on the general soil fertility and the way these nutrients are transported to the roots [21].

The soil chemical status was improved by liming, as described in more detail in a previous paper [1]. Liming increased exchangeable $\mathrm{Ca}, \mathrm{Ca} / \mathrm{Al}^{3+}$ ratio, base saturation, CEC, $\mathrm{pH}-\mathrm{H}_{2} \mathrm{O}$ and $\mathrm{pH}-\mathrm{KCl}$, and decreased soil $\mathrm{Na}$, $\mathrm{Al}^{3+}$ and $\mathrm{H}^{+}$; effects on $\mathrm{Mg}, \mathrm{K}, \mathrm{S}$ and $\mathrm{Mn}$ were negligible. As compared with the threshold levels [3] for soil fertility, seven stands were originally poor or very poor in $\mathrm{Ca}$, four stands were very poor in $\mathrm{Mg}$, four poor or very poor in $\mathrm{K}$ and six (probably seven) poor or very poor in $\mathrm{P}$. Liming improved this clearly for $\mathrm{Ca}$ (four sites had a poor Ca nutrition after liming) and for $\mathrm{Mg}$ to a certain extent (and largest on the two sites where some $\mathrm{Mg}$ was present in the lime product). This improvement in fertility level for $\mathrm{Ca}$ and $\mathrm{Mg}$ was most pronounced in the first years after liming (table II, figure 1). The availability of $K$ (poor on four sites) and of $P$ (poor on seven sites) was not improved. The lack of data on $P$ levels in the soil after liming did not permit an evaluation of the liming effects for $\mathrm{P}$ in the soil directly, so that the foliar analyses (table $V$ ) were used to infer the absence of a $\mathrm{P}$ effect after liming.

Root health appeared to be improved by liming, as shown by the increased $\mathrm{Ca} / \mathrm{Al}$ ratio [6], a higher live/dead ratio of fine roots in the initial years after liming and indications of a higher root life-span [1]. The $\mathrm{Ca} / \mathrm{Al}$ molar ratio in the fine roots expresses the inability or ability to take up nutrients owing to presence or absence of $\mathrm{Al}$ stress. In this study, toxic $\mathrm{Ca} / \mathrm{Al}$ ratios of $0.10-0.20[6,13]$ were alleviated by liming down to a depth of 30 or even $45 \mathrm{~cm}$ and concomitantly, root growth was not only stimulated in topsoil, but also in the deeper layers.

Thus, the higher $\mathrm{Ca}$ availability improved fine root health, amount of fine roots, tree growth and $\mathrm{Ca}$ nutrition (in fine root tissue and in foliage). $\mathrm{Mg}$ was also stimulated to a smaller extent and not only at the sites where some $\mathrm{Mg}$ was in the lime product. Effects on $\mathrm{N}$ nutrition were a decrease of foliar $\mathrm{N}$ by lime at first, followed by 
an increase over time. The fine root contents of $P$ showed a decrease in the most recently limed plots and in the foliage there was a general decrease in P content. To evaluate disequilibria in nutrition, values expressed relative to nitrogen [4] and foliar to root levels are means of detecting potential stress at an early stage [20]. Changes in root concentrations may occur before those in foliage, so that fine root chemical analyses may be powerful indicators of mineral deficiencies at an early stage. Following such comparisons, there were no nutritional disequilibria for $\mathrm{Ca}$ or $\mathrm{Mg}$ after liming (tables $V$ and VI, figure 2). In contrast, they indicated retention of $P$ relative to $\mathrm{N}$ in the fine roots, rather than a preferential transport to the foliage as is the case for $\mathrm{K}$. As the leaves for analysis are collected in the top of the crown, this may suggest that part of the crown and the root system can be low in $\mathrm{K}$ already owing to dilution to the upper crown parts. Thus, $\mathrm{P}$ and $\mathrm{K}$ nutrition may become deficient in the long term.

Since $\mathrm{Ca}$ and $\mathrm{Mg}$ are less limiting after liming, the observed greater amount of fine roots after liming could be an adaptation to low $\mathrm{P}$ and $\mathrm{K}$ levels. These are both elements for which diffusion processes are more important for transport to the root than mass flow, so that an increase in the soil volume explored by fine roots is directly related to a higher access to $\mathrm{P}$ and $\mathrm{K}$ sources [21]. In accordance with this, $\mathrm{Ca}$ is important for cell extension [10], so that a resolved deficiency for this element may explain the higher ability to produce fine roots. On the same sites, liming tended to slightly but significantly increase total number of mycorrhizal tips, but this depended mainly on the increase in fine root length [2]. At the same time, there was an important shift in ectomorphological morphotypes from smooth types with few or no hyphae towards hairy morphotypes with aggregated mycelium in wicks or cords. Hence, the uptake volume was not only increased after liming by increased fine root length, but also as a result of the increase in mycelium [2]. This is in good agreement with the relation between mycorrhizal associations and low phosphorus availability in acid mineral soils [10], which occur at most of the sites used in this study.

\section{Conclusions}

In the fertility range of sites used in this study, moderate doses of lime enhanced fine root biomass of oak both in topsoil and in deeper horizons, and overall fertility and nutrition were improved for $\mathrm{Ca}$ and $\mathrm{Mg}$ but not for $\mathrm{P}$ and $\mathrm{K}$. However, it is possible that the higher amount of fine roots observed in the stands treated with lime, is not only an expression of a higher longevity and improved fine root health (as indicated by higher live/dead and $\mathrm{Ca} / \mathrm{Al}$ ratios of fine roots). It could also be a response to low $\mathrm{P}$ and $\mathrm{K}$ levels, as shown by low total levels of these elements in the soil and the nutrient ratios in foliage/foliage and foliage/root relative to $\mathrm{N}$.

\section{References}

[1] Bakker M.R., Fine-root parameters as indicators of sustainability of forest ecosystems, For. Ecol. Manage. 122 (1999) $7-16$.

[2] Bakker M.R., Garbaye J., Nys C., Effect of liming on the ectomycorrhizal status of oak, For. Ecol. Manage. (1999) in press.

[3] Bonneau M., Fertilisation des forêts dans les pays tempérés. Théorie, bases du diagnostic, conseils pratiques, réalisations expérimentales, Engref, Nancy, 1995, 366 p.

[4] Boxman A.W., Cobben P.L.W., Roelofs J.G.M., Does $(\mathrm{K}+\mathrm{Mg}+\mathrm{Ca}+\mathrm{P})$ fertilization lead to recovery of tree health in a nitrogen stressed Quercus rubra L. stand?, Environ. Pollut. 85 (1994) 297-303.

[5] Brêthes A., Ulrich E., Renecofor - Caractéristiques pédologiques des 102 peuplements du réseau, Office national des forêts, dép. recherches techniques, 1997, 573 pp.

[6] Cronan C.S., Grigal D.F., Use of calcium/aluminium ratios as indicators of stress in forest ecosystems, J. Environ. Qual. 24 (1995) 209-226.

[7] Eissenstat D.M., Yanai R.D., The ecology of root lifespan, Adv. Ecol. Res. 27 (1997) 1-60.

[8] Helmisaari H.-S., Vitality of trees and forest ecosystems - concepts and criteria, in: Andersson F., Braekke F., Hallbäcken L. (Eds.), Imbalanced Forest Nutrition - Vitality Measures. A SNS-project 1993-1996, Final and Work Report, Section of Systems Ecology, Swedish University of Agricultural Sciences, 1997, p 158-175.

[9] Hüttl R.F., Die Nährelementversorgung geschädigter Wälder in Europa und Nordamerika, Freib. Bodenkl. Abh. 28, University of Freiburg, Germany, 1991, 440 p.

[10] Marschner H., Mineral Nutrition of Higher Plants, 2nd ed., Academic Press, London, 1995.

[11] Olsthoorn A.F.M., Tiktak A., Fine root density and root biomass of two Douglas-fir stands on sandy soils in the Netherlands. 2. Periodicity of fine root growth and estimation of belowground carbon allocation, Neth. J. Agr. Sci. 39 (1991) $61-77$.

[12] Persson H., Majdi H., Clemensson-Lindell A., Effects of acid deposition on tree roots, Ecol. Bull. 44 (1995) 158-167.

[13] Puhe J., Persson H., Börjesson I., Wurzelwachstum und Wurzelschäden in Skandinavischen Nadelwäldern, Allg. Forst. Zeitschr. 20 (1986) 488-492.

[14] Raspe S., Fine root development, in: Hüttl R.F., Schaaf W. (Eds.), Magnesium Deficiency in Forest Ecosystems, Kluwer Academic Publishers, 1997, pp. 309-332.

[15] Rost-Siebert K., Untersuchungen zur H- und AlToxizität an Keimpflanzen von Fichte (Picea abies Karst.) und 
Buche (Fagus sylvatica L.) in Lösungskultur. Berichte Forschungszentrum Waldökosteme, Universität Göttingen 12 (1985) 1-219.

[16] Tennant D., A test of a modified line intersect method of estimating root length, J. Ecol. 63 (1975) 995-1001.

[17] Trüby P., Eine Titrationsmethode zur simultanen Bestimmung von $\mathrm{H}^{+}$und Aluminium in $\mathrm{NH}_{4} \mathrm{Cl}$-bodenextrakten, Z. Pflanzenernähr. Bodenk. 152 (1989) 297-300.

[18] Unistat Ltd, Unistat Version 4 for Windows, 1995.
[19] Van den Burg J., Olsthoorn A.F.M., National research project on forest fertilisation. 1985/86-1991/92, IBN Research Report 96/10, IBN-DLO, Wageningen, the Netherlands, 1996, $43 \mathrm{p}$.

[20] Vogt K.A., Publicover D.A., Bloomfield J., Perez J.M., Vogt D.J., Silver W.L., Belowground responses as indicators of environmental change, Environ. Exp. Bot. 33 (1993) 189-205.

[21] Yin X., Perry J.A., Dixon R.K., Temporal changes in nutrient concentrations and contents of fine roots in a Quercus forest, For. Ecol. Manage. 44 (1991) 175-184. 